\title{
軌条輪上での実台車加振実験による鉄道車両の地震時脱線メカニズムの検証*
}

\author{
足立 昌仁 ${ }^{* 1}$, 森村 勉 ${ }^{* 2}$, 西村 和彦 ${ }^{* 3}$, 曄道 佳明 ${ }^{* 4}$
}

\section{Study on the Derailment Mechanism of Railway Vehicle by Earthquake Ground Motion with a Full Scale Bogie on Roller Rigs}

\author{
Masahito ADACHI ${ }^{*}$, Tsutomu MORIMURA, Kazuhiko NISHIMURA and Yoshiaki TERUMICHI \\ ${ }^{* 1}$ Technology Research and Development Department(KOMAKI), Central Japan Railway Company \\ 1545-33 Ohyama, Komaki-shi, Aichi, 485-0801 Japan
}

The derailment mechanism for when earthquakes occur has been verified in vibration bench tests and simulations in the past. However, in the past full-scale vibration bench tests including ours, the wheels did not rotate. The aims of this study are to verify the derailment mechanism in case that the railway vehicle running at a high speed is vibrated by a large lateral displacement of track during earthquakes, and to reconfirm the past other verifications. In order to realize this aim, we conducted the full-scale vibration tests with an actual series N700 bogie on roller rigs by use of the rolling stock field test simulator. This apparatus enables to simulate running tests with one or half rolling stock on roller rigs which can experience a considerable degree of horizontal displacement. As a result of this vibration test with an actual bogie on roller rigs, we were able to confirm the influence of wheel rotation on the wheel lift motion, the anti-derailing guard rail acting on a rotating wheel, and so on.

Key Words : Railway, Earthquakes, Seismic Motion, Simulation, Derailment

\section{1. 緒言}

鉄道車両の地震時の脱線挙動に関し，実験やシミュレーションによる様々な研究が実施されてきた(1)-(5). その背景として，1995 年の兵庫県南部地震， 2004 年の新潟県中越地震での脱線事故が，研究を促進寸る大 きな契機になった. 東海道新幹線では, 新潟県中越地震以後, 地震対策の検討を進め, 2011 年より脱線・逸 脱防止対策を進めているが，その対策検討の一環として，我々は地震時の脱線メカニズム解明に関する様々 な研究を実施してきた. 地震時の大加振による車両の脱線挙動を観測するため, 実台車による振動台試験(6)(7), 縮尺 $1 / 5$ 模型車両による定置加振試験( ${ }^{(8)}$, 縮尺 $1 / 10$ 模型車両による軌条輪上での加振試験 ${ }^{(9)}$ を実施した。これ

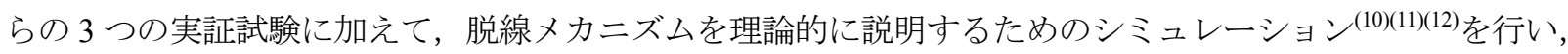
地震時の脱線メカニズムおよび脱線防止対策（脱線防止ガード）効果に関する多くの知見を得ることができ た．そして，これらの結果を組み合わせることで地震時のロッキング脱線メカニズムを解明し，脱線防止ガ ードの有効性を結論づけた。しかしながら，実物車輪が回転状態で加振する実証試験については未確認であ ったことから，我々は新たに 2008 年に技術開発部（小牧研究施設）で本格稼働した車両走行試験装置(図 1) において，地震を模擬した大变位加振試験の実験準備を整え，実物台車の車輪が回転した状態での加振試験 を実施した ${ }^{(13)}$

* 原稿受付 2013 年 7 月 10 日

${ }^{* 1}$ 正員，東海旅客鉄道(株) 技術開発部（广453-0801 愛知県小牧市大山 1545-33）

*2 正員，フェロー，東海旅客鉄道(株）（テ108-8204 東京都港区港南 2-1-85）

*3 正員，東海旅客鉄道(株）新幹線鉄道事業本部（广100-0005 東京都千代田区丸の内 1-9-1）

*4 正員, 上智大学理工学部（广102-8554 東京都千代田区紀尾井町 7-1）

E-mail: adachi@jr-central.co.jp 
本研究は，車両走行試験装置の軌条輪上で車輪回転状態の実物台車が大変位加振される時の車両挙動を詳 細に分析するとともに，これまでの実験やシミュレーションとの比較を行いながら，地震時の脱線メカニズ ムおよび脱線防止ガード効果に関する考察を行う.

\section{2. 本研究の意義}

表 1 に，地震時の脱線メカニズム解明のために実施したこれまでの取り組みを示す．既に，表 1 の個々の取り 組みについては各文献で報告済みであるが，全体の取り組みにおけるそれぞれの役割について以下に概要を説明 する．表 1 の1)から(3)が，これまでに実施した 3 つの実証実験である．表 1 の(1)の実台車振動台試験では，実物 の脱線防止ガードを取り付けたバラスト軌道上で，想定東海地震波や様々な地震波，正弦波での加振試験を繰り 返し行い，実物の脱線メカニズムと脱線防止ガード効果を確認した. 特に想定東海地震波（高架橋応答波 左右最 大加速度 $1300 \mathrm{gal}$ ，左右最大変位 $333 \mathrm{~mm}$ ）での加振試験により脱線防止ガードが脱線を防止したことで，実物の 脱線防止ガードの有効性を確認することができた. 更に, 実台車振動台試験を補完するため, 表 1 の(2)の縮尺 $1 / 5$ 模型において，実物では装置の制約上実施することが困難な，より大変位で大量の加振試験を行い，より広範囲 での脱線メカニズムと脱線防止ガード効果を確認した。 また，想定東海地震波（高架橋応答波）において 1.4 倍 まで脱線防止ガードが有効に機能することを確認した. ただし, 実台車振動台試験と縮尺 $1 / 5$ 模型加振試験では, 車輪が停止した状態であることから，更に表 1 の3の軌条輪上で縮尺 $1 / 10$ 模型の車輪を回転させた状態で加振試 験を行い，車輪回転状態が脱線メカニズムに及ぼす影響を調べた．その結果，車輪回転状態でも脱線メカニズム は停止状態と同じく図 2 に示すようなロッキング脱線であり，それらに対して脱線防止ガードは有効に作用する ことを確認した．そして，これらの3つの実証試験に加えて，表 1 の(4)車両運動シミュレーションモデルを作 成し，110実台車振動台試験を再現できるまで車両モデルの精度を高め，そのモデルで車輪回転時の脱線メカニ ズムと脱線防止ガード効果を予測した．具体的には，シミュレーションで停止状態と車輪回転状態の違いや，車 体質量, 地震上下動, 曲線通過が脱線メカニズムに及ぼす影響を調べ，それらの影響が小さいことを確認した。

以上が，これまでの取組みの詳細であるが，実証という観点では，実物台車による車輪回転状態での脱線メ力 ニズムと脱線防止ガード効果は，表 1 の通り実証できていない. また，(4)のシミュレーションは，前述の通り (1) の実台車振動台試験を基に精度を高めたが，車輪回転状態での実物大の加振試験と比較することができれば，更 にシミュレーションの妥当性を確かめることができる。したがって，我々は新たに車輪回転状態での実物台車加 振試験に取り組むこととした。本研究の具体的な目的は以下の通りである.

（1）実物台車が車輪回転している状態での脱線メカニズムと脱線防止ガードの作用を確認する.

（2）車輪回転状態で車輪がフランジ高さ相当 $(30 \mathrm{~mm})$ 上昇する時の加振条件を調べ，(4)のシミュレーション結果 と定量的に比較し, シミュレーション精度を確認する.

（3）車輪がフランジ高さ相当上昇する時の加振条件について，(1)の実台車振動台試験（車輪停止状態）と比較す ることで車輪回転状態の影響を調べる．また，(4)のシミュレーションと傾向を比較する.

Table 1 Variety of conventional approaches for analysis on derailment mechanism

\begin{tabular}{|c|c|c|}
\hline Wheel condition & Stationary & Rotational \\
\hline $\begin{array}{c}\text { Full-scale model } \\
\text { excitation test }\end{array}$ & $\begin{array}{c}\text { (1) } \begin{array}{c}\text { Half vehicle (an actual bogie, a half } \\
\text { vehicle body) and a ballast track } \\
\text { on a shaking table }\end{array} \\
\text { (6)(7) }\end{array}$ & $\begin{array}{c}\text { (3) } 1 / 10 \text { scale half vehicle } \\
\text { on roller rigs }\end{array}$ \\
\hline $\begin{array}{c}\text { Scale model } \\
\text { excitation test }\end{array}$ & $\begin{array}{c}\text { (2) } 1 / 5 \text { scale half vehicle and a track } \\
\text { on a shaking table }\end{array}$ & (4) Half vehicle model on a track (two rails) model ${ }^{(10)(11)(12)}$ \\
\hline Simulation & \multicolumn{2}{|c|}{ (4) } \\
\hline
\end{tabular}




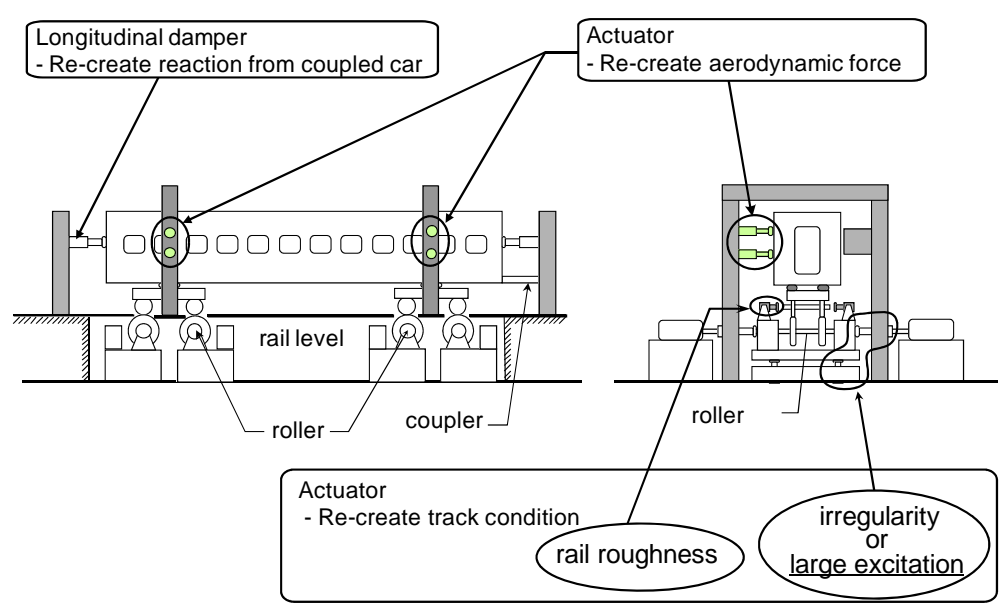

Fig.1 Rolling stock field test simulator

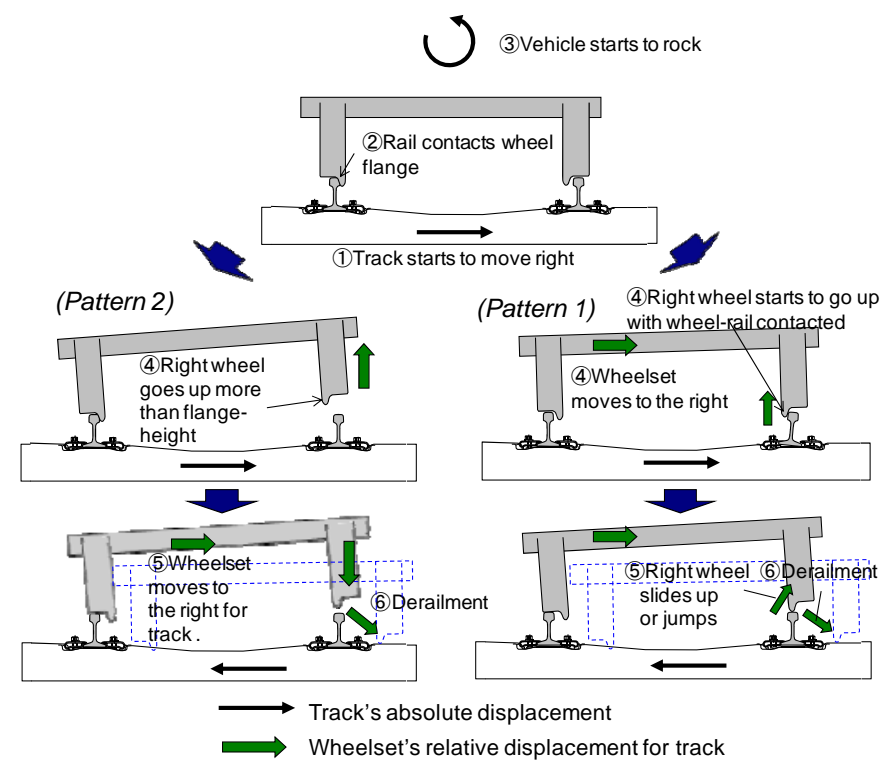

Fig.2 Rocking derailment mechanism during earthquakes ${ }^{(8)}$

\section{3. 試験条件}

\section{$3 \cdot 1$ 試験設備（車両・軌条輪）}

図 3 に軌条輪上での実台車加振試験の全景を示寸. 図 3 に示寸ように, N700 系台車を軌条輪上に載せ, その上 に 1 車体の半分の荷重を模擬する荷重枠を載せて 1 両の半分の質量特性を模擬している. 地震時のロッキング脱 線は，図 2 に示寸ように軌道の左右動の動きに対し，主として車両のローリング運動と上下・左右方向の並進運 動を伴いながら生じる．地震時には 1 両が同一の地震動を受けると想定すると，車両の前後にある台車の動きは 同一であることから，1両の半分を模擬した半車体 1 台車で評価することとした.

荷重枠はピッチングとヨーイングと前後の動きを拘束するリンク装置で地上側に固定される。このリンク装置 は，荷重枠のローリング方向と上下・左右方向の動きをほとんど拘束しない構成とし，運動特性への影響が極力 小さくなるよう，アルミ合金製として軽量化(片側 600kg)を図っている.

また，軌条輪を水平方向に大きく加振するため, 荷重枠の上部と左右両側には, 安全上を考慮して荷重枠の上 下と左右の変位を規制するためのストッパを配置している，また，車輪回転中の加振によって万一車輪が軌条輪 
から逸脱しようとするのを防止するため, 軸箱の異常上昇止めを設けている. 補足として, 図 4 の(a) と(b)に, そ れぞれ荷重枠・地上間のリンク装置の拡大写真と軸箱の異常上昇止めの側面写真を示寸. 図 4(a)に示寸ように, リンク装置は 2 本のリンクで構成され，各結合部はローリング方向に自由に回転することが可能であり，荷重枠 のローリング方向と上下・左右方向の運動を妨げない. また, 図 4(b)の異常上昇止めの側面写真に示すように, 軸箱下から円筒状のアルミ製の棒を門型フレームの中に通しており, 車輪が約 $60 \mathrm{~mm}$ 上昇する場合には, 円筒上 の棒が門型フレームと上下に接触することによって，それ以上車輪が上昇することを防止する機能を有する.

車両の軸重は 10.0ton とし，車体を模擬する荷重枠は $13.7 \operatorname{ton}$ (但し，2 個のリンク装置質量 $1.2 \operatorname{ton} の$ 半分を算入) としている. 台車については, 軸箱下部に異常上昇止め(120kg/1 軸箱)を取り付けているため, ばね下質量の増加 分を歯車装置の撤去とブレーキディスク表面を削ることで, 相殺している. また，加振試験時のロッキング挙動 によって車体〜台車間の上下変位が大きくなるため，車体を支持する空気ばねは大変位に対応できる構造として いる. また, 車体〜台車間のヨーダンパについては, 車体〜台車間の上下方向の大変位に耐えられないことから, 実台車振動台試験(6)(7) と同様, 装備をしていない. また車両各部のパラメータも, 実台車振動台試験(6)(7) 時の仕様 とほぼ同等である.

図 5(a)(b)に，軌条輪上での車輪と実軌道上の車輪の拡大図を示す．図 5(a)の軌条輪は，レール相当部分（60kg レールと同じ断面形状）と模擬の脱線防止ガードおよび安全装置により構成され，軌条輪の脱線防止ガードの位 置は，図 5(b)の実軌道上の脱線防止ガード位置と同じである．左右の軌条輪は回転軸で結合された一体構造とな っており, 継手を介し電動機により回転する.また, 軌条輪は回転しながら油圧アクチュエータによって左右方 向に大変位させることが可能である（加振部位は図 6 を参照).

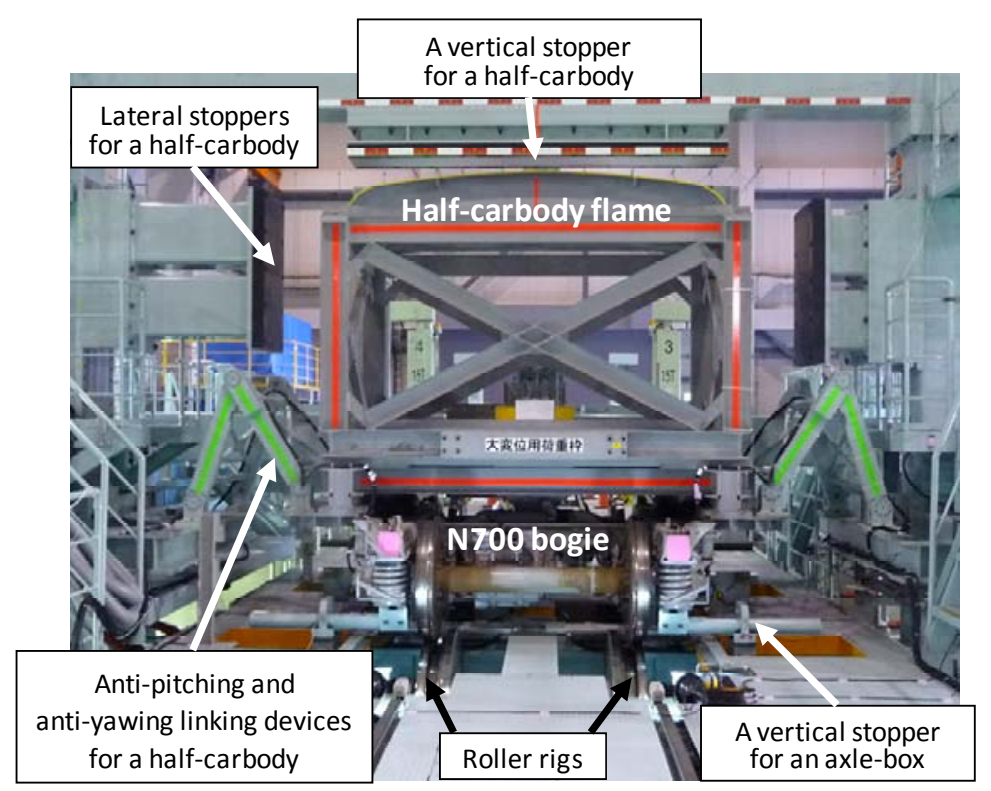

Fig.3 Full view of a full-scale excitation test with an actual bogie on roller rigs

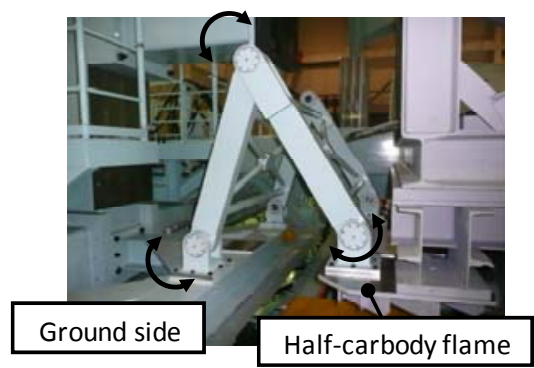

(a) a link device for a half-carbody (front view)

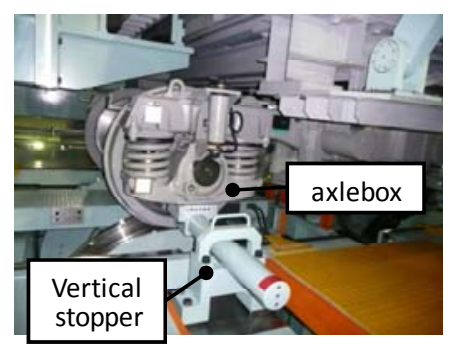

(b) a vertical stopper for an axlebox (side view)

Fig.4 Close-up of a link device for a half-carbody and a vertical stopper for an axlebox 


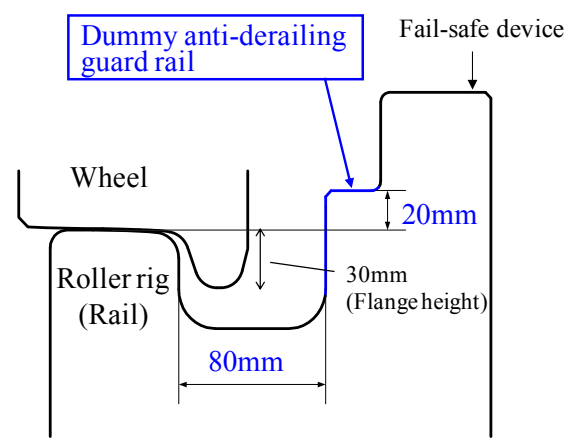

(a) A wheel and a dummy guard rail on a roller rig

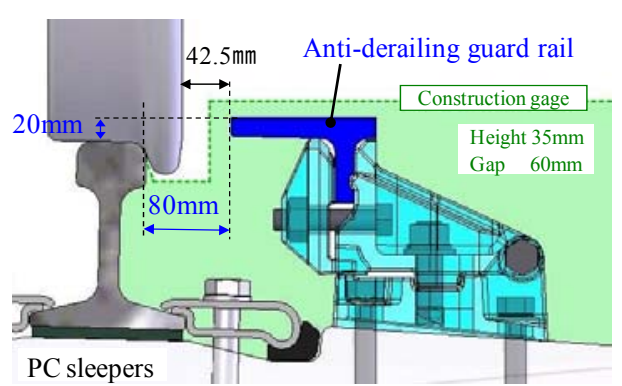

(b) A wheel and an anti-derailing guard rail ${ }^{(14)}$

Fig.5 A wheel on a roller rig and a wheel on an actual track with anti-derailing guard rail

\section{$3 \cdot 2$ 測定項目}

図 6 に，加振試験および測定の概念図を示す．測定項目は，脱線メカニズム解明を行う観点から，軌条輪の左 右変位（前後軸 2 点）, 輪軸の左右変位（前後軸 2 点）, 軸箱の上下変位（計 4 点）, 台車枠の上下変位（左右 2 点), 台車枠の左右変位（前後 2 点）, 荷重枠の上下変位（左右 2 点）, 荷重枠の左右変位（前後 2 点）, 各車輪の 輪重（計 4 点）と横圧（計 4 点）とする. 台車と荷重枠とも，上下方向と左右方向の変位については，それぞれ 2 点ずつ測定することで，並進方向の変位と回転角を算出できるよう配慮している.

変位測定にはレーザー式変位計を使用し, サンプリング周波数を $500 \mathrm{~Hz}$ とし $100 \mathrm{~Hz}$ のローパスフィルタ処理し たデータを用いる. 輪重・横圧については新連続式とし, サンプリング周波数 $2500 \mathrm{~Hz}$ のデータを新連続処理装 置で処理されたデータ（同時に $100 \mathrm{~Hz}$ ローバスフィルタ処理）を用いる. 各変位データは, 軸箱上下変位を除き, 地上に設置したレーザー変位計から車両の対象物にレーザーを照射することで得られるが，加振により対象物が 想定以上に大きく変位してしまい，データとして久けが生じる場合がある．車輪上昇量については，軸箱上下変 位量の結果を車輪位置に換算して求めた結果を用いる.

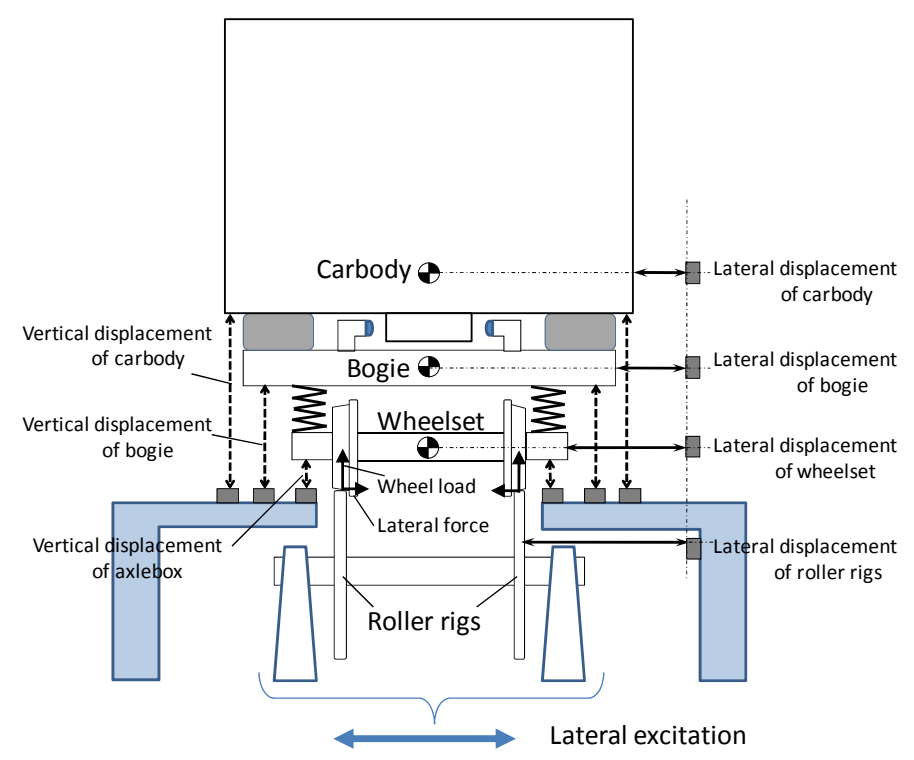

Fig.6 Image of an excitation test and measurement

\section{$3 \cdot 3$ 加振条件}

これまで表 1 の 3 つ加振試験とシミュレーションにおいては, 正弦波加振試験や地震波加振試験での評価を 行ってきたが，両試験のそれぞれの目的は，正弦波加振が様々な周波数と振幅で広範囲に脱線メカニズムを解明 すること, 地震波加振がこれまでに生じた実際の地震波や今後想定される地震波で加振される場合の脱線防止ガ 
ード効果を確認することであった．今回の軌条輪上での実台車加振試験の主目的は，実物台車が車輪回転状態で 大変位加振を受ける場合の脱線メカニズムを調心゙, これまでに得られた結果と比較することである. したがって, 今回の大変位加振試験では, それぞれの加振周波数において車輪が $30 \mathrm{~mm}$ 上昇するときの振幅条件を比較するこ とが妥当であると考え，正弦波加振試験を行うこととした.

図 7 に正弦波の加振波形を示寸，加振波形は，加振される質量が非常に大きいことから，最初の 3 波で徐々に 振幅を増幅し，次の 2 波（矢印の範囲）は目標振幅で加振し，その後の 3 波で徐々に減衰させることとする. 地 震時の車両挙動は, 徐々に振幅を大きく寸る場合でも, 最初から一定振幅を繰り返し与える場合でも, 加振振幅 の最大值でほぼ定まることを，過去の実験（表 1）にて確認済みである.

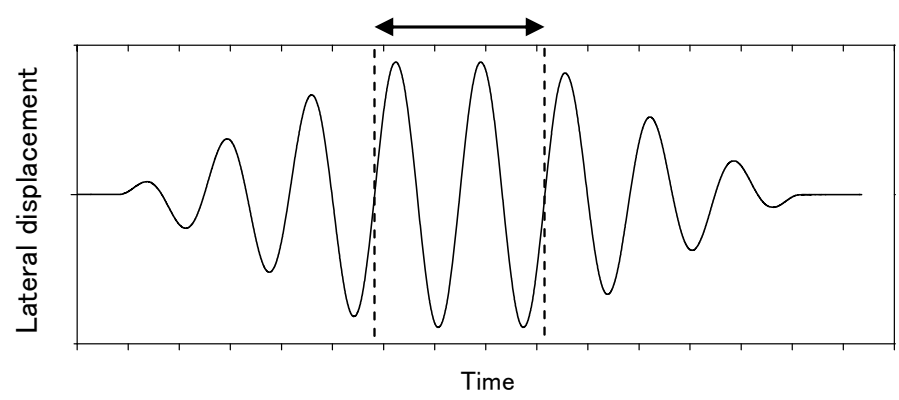

Fig.7 Example of a sinusoidal waveform for the excitation test

加振周波数については $0.5 \mathrm{~Hz}$ から $1.5 \mathrm{~Hz}$ とした。この周波数の選定理由は次の通りである.

(1)既報告の実車のシミュレーション解析 ${ }^{(10)(11)}$ や軌条輪上での $1 / 10$ 模型加振試験 ${ }^{(9)}$ において, 加振周波数が比較的 低い領域（シミュレーションで $0.8 \mathrm{~Hz}$ 以下， $1 / 10$ 模型試験で $2.8 \mathrm{~Hz}$ [実物換算 $0.9 \mathrm{~Hz}$ ]以下）で，走行速度が脱線限 界に及ぼす影響が顕著であったこと。

(2)一方，加振周波数が比較的高い場合（シミュレーション(10)(11)で $1.5 \mathrm{~Hz}$ 以上， $1 / 10$ 模型加振試験(9)でも $4.7 \mathrm{~Hz}[$ 実 物換算 $1.5 \mathrm{~Hz}]$ 以上) では, 走行速度が脱線限界に及ぼす影響があまり見られないという結果が得られていること.

(3)想定東海地震波（高架橋応答波）で加振をした場合に脱線挙動が生じるときの変位波形は，既報告の実台車振 動台試験 ${ }^{(7)}$ の通り，左右加速度が最大付近で， $1.2 \mathrm{~Hz}$ の正弦波形状と概ね一致することから，1.2Hzにおける脱線 挙動を詳細に評価できること.

軌条輪の回転速度については, 水平方向に $100 \mathrm{~mm}$ 以上大変位を付与寸る場合は, 回転力と水平変位を伝達す る継ぎ手性能の制約から，軌条輪の回転速度を $150 \mathrm{~km} / \mathrm{h}$ とした．この速度は，実車のシミュレーション解析(10)(11)

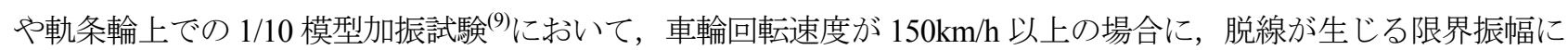
及ぼす影響が小さいことを確認しており， $150 \mathrm{~km} / \mathrm{h} て ゙$ 速度影響を概祆確認できると考えた.

加振試験の手順は，軌条輪を $150 \mathrm{~km} / \mathrm{h}$ まで加速して一定速度となった後に，設定した加振周波数において正弦 波加振を行う. 付与する変位振幅は, 加振試験の結果, 車輪上昇量の最大值が車輪フランジ高さ $(30 \mathrm{~mm})$ 未満 であれば, 数 $\mathrm{mm}$ 単位で慎重に変位振幅を増加し, 次の試験を行う。試験時の車輪上昇量が $30 \mathrm{~mm}$ に到達した場 合は，安全上および試験装置と車両の強度上，可能であれば加振振幅を $1 \mathrm{~mm}$ 単位で増加して試験を継続する.

\section{4. 車両走行試験装置による大变位加振試験}

\section{$4 \cdot 1$ 時刻歴応答波形による挙動把握}

本節では, 時刻歷応答波形の代表例として, 周波数 $0.6 \mathrm{~Hz}$ ・変位振幅 $222 \mathrm{~mm}$ と周波数 $1.2 \mathrm{~Hz}$ ・変位振幅 $124 \mathrm{~mm}$ の 2 つ大変位加振試験において得られた時刻歴応答波形を基に，車両のロッキング挙動について説明する.

(1) 周波数 $0.6 \mathrm{~Hz}$ ，変位振幅 $222 \mathrm{~mm}$ の正弦波加振試験 
図 8 から図 12 にそれぞれ，周波数 $0.6 \mathrm{~Hz}$ ，変位振幅 $222 \mathrm{~mm}$ の正弦波加振で得られた，軌条輪と輪軸の左右変 位，車体（ばね上）・台車（ばね間，本章では特にことわりがない限り便宜上輪軸を除く台車部分を意味する）・ 輪軸（ばね下）のロール角, 車輪上昇量, 横圧, 輪重の波形を示す. 各図で示す軌条輪と輪軸のデータは進行方 向に対して後軸を代表として示す. 理由は, レーザー変位計の出力結果の乱れが少なかったため後軸としたが, 軌条輪・輪軸ともに前後軸の動きはほとんど同じであり後軸で問題はない.

図 8 に示すように，輪軸と軌条輪の左右変位については，両者の左右変位はほぼ一致する。ただし，両者の動 きには若干の差が生じ，例えば軌条輪の向きが変わる付近では，輪軸左右変位のピークの方が少し大きくなる. これは, 車輪のフランジ部と軌条輪の間には左右方向に隙間があるため, 左右相対変位が生じることに起因する. 図 8 の 7 秒付近（A 部）を例にとると，右方向（図 8 の下向き矢印）に移動していた軌条輪が左方向（図 8 の上 向き矢印）に折り返す場合に，車両（輪軸）は慣性で右方向への移動を継続するため，右車輪のフランジ部が軌 条輪と接触するまで輪軸は右へ移動し続ける（図 11 の 7 秒付近（A 部）の右車輪の横圧は，前述のようにフラン ジ部が軌条輪と接触したことを示す)。したがって，輪軸と軌条輪の動きには差が生じる.

図 9 の車両各部のロール運動については，まず車体のロール角に着目すると，ほぼ正弦波状の波形を示す．こ こで，ロール角は，時計回りを正とする．測定波形を例に説明すると，図 8 の 1 秒付近（B 部）で軌条輪が中央 位置から左方向に動きはじめると，図 9 の 1 秒付近（B 部）では車体ロール角は正となり時計回りに傾いた状態 となる. 同様に, 図 8 の 8 秒手前付近（C 部）で，軌条輪が左端から右方向に動きはじめると，図 9 の車体口ー ル角は負となり，反時計回りに傾いた状態となる。図 9 において，台車と輪軸のロール角は，車体ロールと概ね 同じ傾向を示すが，詳しく見ると台車・輪軸ともそれぞれの方向に傾いた際，2つのピークがある. 例えば，図 9 の 8 秒手前付近（C 部）の台車ロール角の 1 つめのピークは，軌条輪が左端から右方向に折り返すタイミングで あり，2つのめのピークは，車体ロール角のピークとほぼ一致する.

図 10 に示すように，車輪の上昇については，左車輪と右車輪が交互に生じる。このため，図 12 に示すように

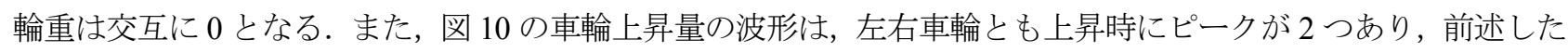
台車・輪軸のロール角の 2 つのピークのタイミングはほぼ一致する. 7〜 7.5 秒付近を例にとると, 図 8 の 7 秒付 近 (A 部) で軌条輪が右端から折り返して左方向に向かって移動を開始する時，図 10 （A 部）のように左側車輪 が上昇を開始する。このとき，図 11 (A 部) の右車輪の横圧が急峻に立ち上がっており，図 10 (A 部) の車輪上 昇の 1 つ目のピークおよび図 9 (A 部) の輪軸・台車ロール角の 1 つ目のピークとタイミングがほぼ一致する. また，図 10 の車輪上昇の 2 つ目のピークは，図 9 の車体ロール角のピークとタイミングがほぼ一致する.

車輪上昇量に 2 つピークが生じる理由については，以下のように考えられる. 図 10 の 7 秒付近 (A 部) を例 にとると，まず左車輪が上昇するきっかけは，図 8（A 部）で軌条輪が右端から左方向に折り返して移動するこ とで車両に対して右方向に大きな慣性力が生じ，右車輪のフランジ部を支点として時計周りに大きな回転モーメ ントが作用することによる（図 13(a)）。その後, 図 8 の軌条輪の左方向への加速度が小さくなり車両に生じる右 方向への慣性力が減少するため, 図 10 (A 部) の車輪上昇は一旦減少しようとするが (図 13(b)), 車体のロール 角は図 9 (A 部) で示すように車輪上昇が一旦減少するときにおいても増加しつづける. これは，車体は空気ば ねで台車に柔支持され，且つ車体・台車間の上下方向および左右方向の相対変位は，車体・台車間の変位規制ス トッパが接触するまで許容されており, 車体と台車は必ずしも同一の動きとはならないためである. その後，図 9 (A 部) を見ると，車体ロール角が 50～100mrad となったため車体から台車に大きな力が作用し，台車と輪軸 は車体（車体のロール慣性モーメントは台車（輪軸含む）の約 7 倍）に追従してロール角が再度大きくなり，車 輪上昇量が再度増加したと考えられる (図 13(c)).

次に車輪がレール上に着地するタイミングについては, 図 10 の左車輪は, 7.5 秒付近（D部）でレール上に着 地する.このとき, 図 8 (D 部) では軌条輪の左右変位が $0 \mathrm{~mm}$ (中央位置) を通過するタイミングである.また, 図 11 の右車輪の横圧も，7.5 秒付近（D 部）で急激に減少している. 軌条輪が中央位置付近を通過する際には, 軌条輪の移動速度はほぼ一定であることから車両に作用する慣性力はほぼ 0 であり，したがって，図 9 の 7.5 秒 付近（D 部）で車体のロール角も減少中である.

これらのことから，車輪の上昇・下降の挙動は，軌条輪が左右方向に動くことで車両の各部がロール運動し， 車両全体としてはロッキングをすることによって発生していることが分かる. $0.6 \mathrm{~Hz}$ のような比較的加振周波数 が低い場合は, 軌条輪が左右端付近から折り返した直後に車体のロール角が最大となり, 且つ車輪上昇量も最大 
となることがわかった．また，このときの車両のロール運動は，車両の特性から下心ローリングであり，車体の ロール角が最大となるときに車体上部が左右に大きく摇さぶられるのが特徵である.

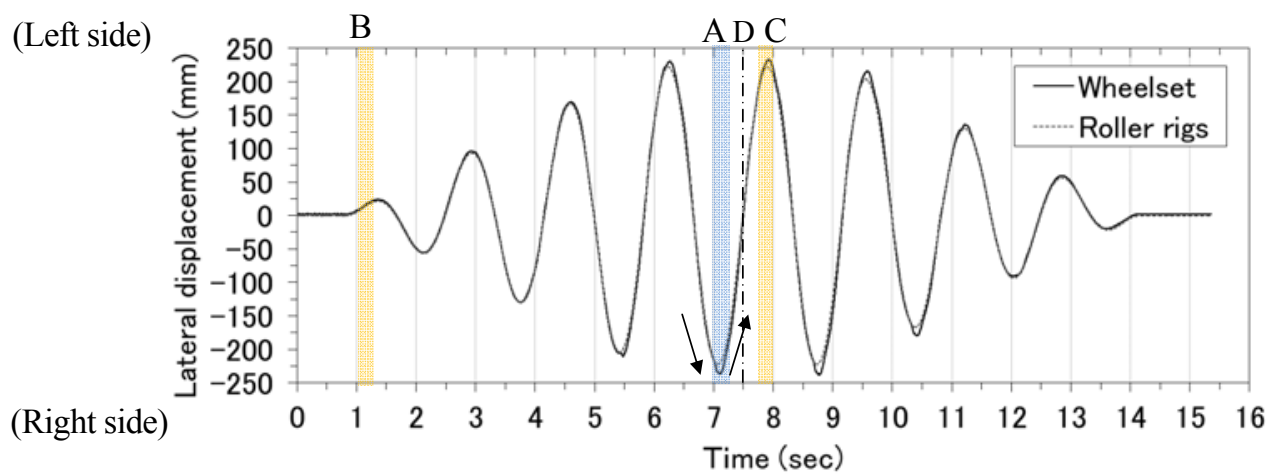

Fig.8 Lateral displacement of a wheelset and roller rigs(frequency $0.6 \mathrm{~Hz}$, maximum amplitude $222 \mathrm{~mm}$ )

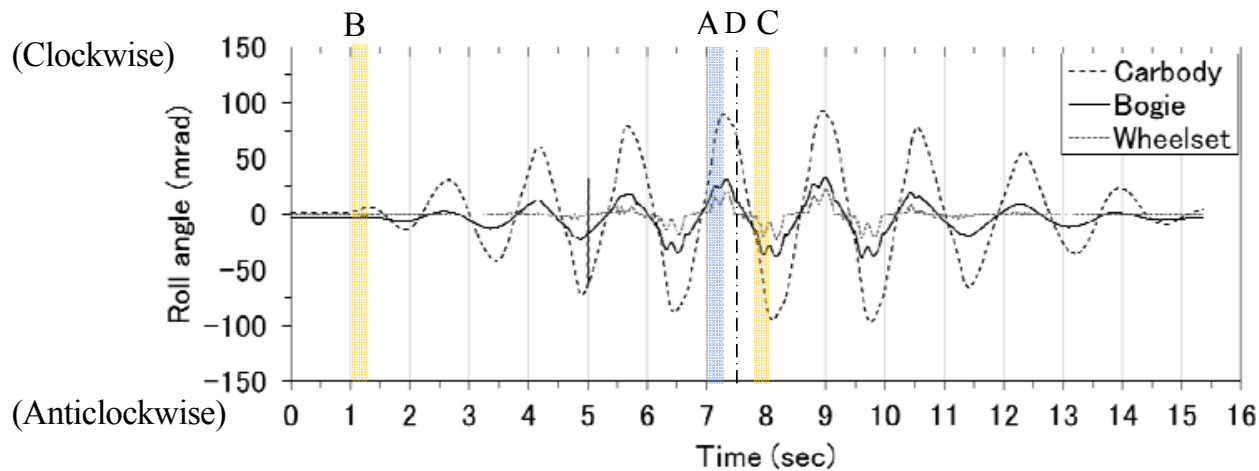

Fig.9 Roll angle of a carbody, bogie and wheelset (frequency $0.6 \mathrm{~Hz}$, maximum amplitude 222mm)

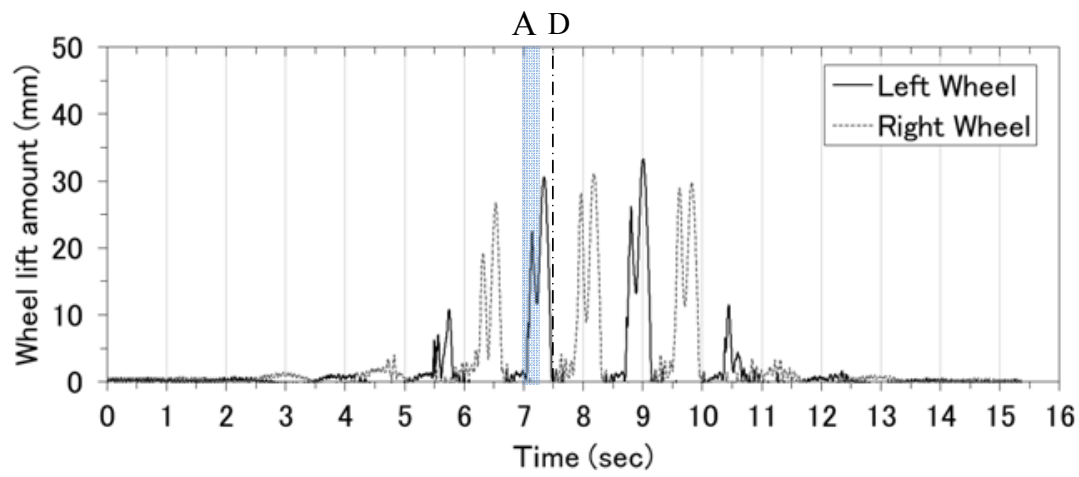

Fig.10 Lift amount of a left and a right wheel (frequency $0.6 \mathrm{~Hz}$, maximum amplitude 222mm)

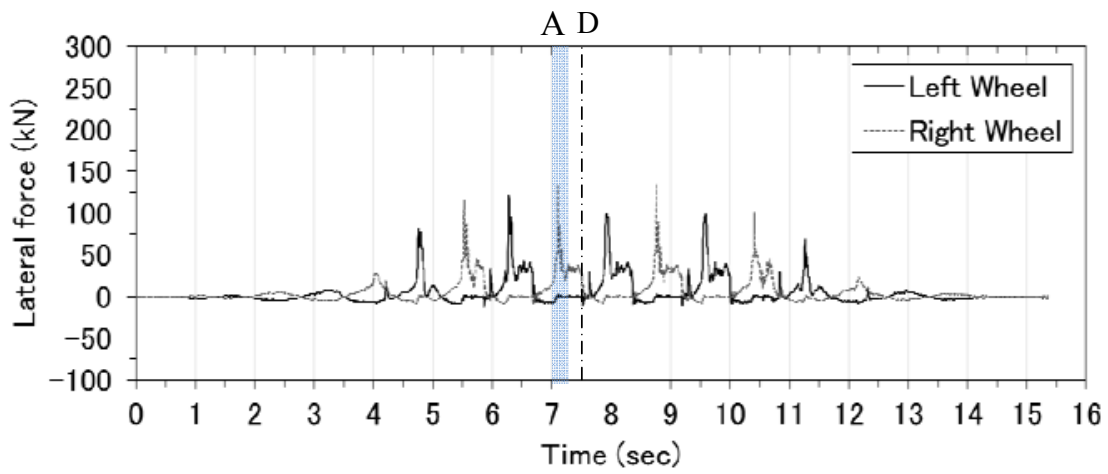

Fig.11 Lateral contact force between wheels and roller rigs (frequency $0.6 \mathrm{~Hz}$, maximum amplitude $222 \mathrm{~mm}$ ) 


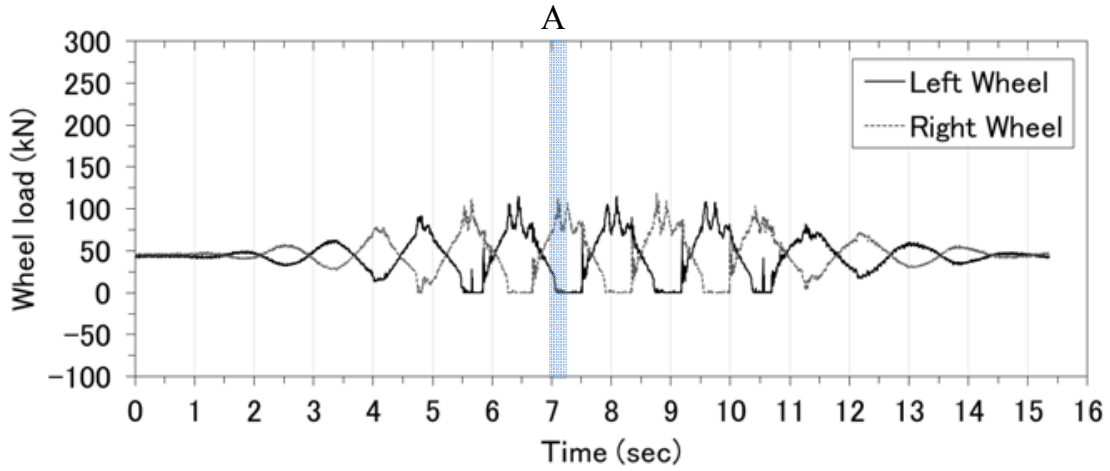

Fig.12 Vertical contact force between wheels and roller rigs (frequency $0.6 \mathrm{~Hz}$, maximum amplitude 222mm)

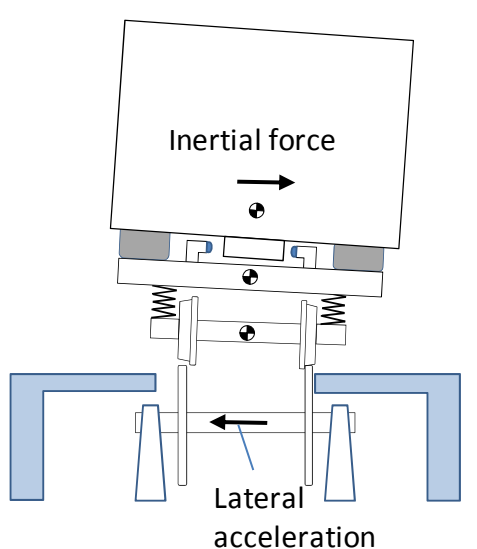

(a) 1st peak of a wheel lift amount

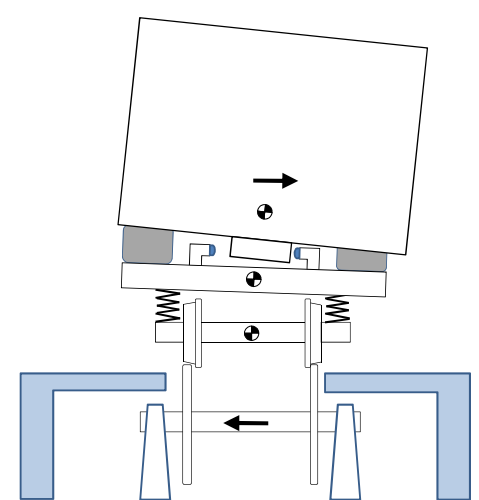

(b) Decrease of a wheel lift amount

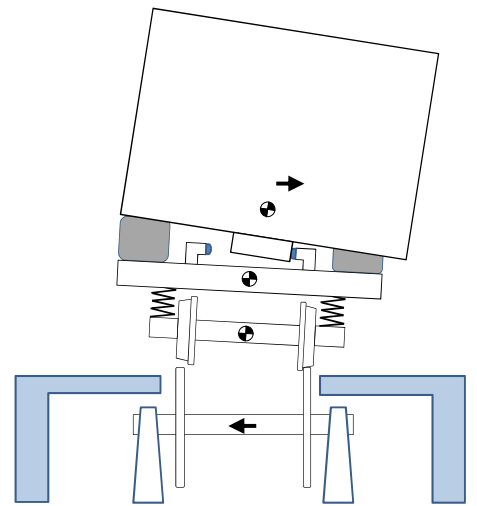

(c) 2nd peak of a wheel lift amount

Fig.13 Relation between vehicle dynamics and displacement of roller rigs

(2) 周波数 $1.2 \mathrm{~Hz}$ ，変位振幅 $124 \mathrm{~mm}$ の正弦波加振試験

前述した本節(1)と同様に, 図 14 から図 18 に, 周波数 $1.2 \mathrm{~Hz}$, 変位振幅 $124 \mathrm{~mm}$ の正弦波加振で得られた, 軌条 輪と輪軸の左右変位，車体（ばね上）・台車（ばね間）・輪軸（ばね下）のロール角，車輪上昇量，横圧，輪重の 波形例（いずれも進行方向の後軸）を示す。この測定波形は，脱線防止ガードが車輪に作用し脱線が防止された ときの波形である.

図 14 の輪軸と軌条輪の左右変位については，図 7 の場合と同様，両者はほとんど一致する.ただし，図 14 (E 部）の 5 秒を過ぎて，軌条輪が左端から右方向に折り返し（約 5.25 秒），右端位置（約 5.6 秒）にまでの間に，輪 軸が軌条輪の動きに追従できずに徐々に乘離している様子が波形から読み取れる．また，図 15 (E 部）で輪軸の ロール角が約 5.25 から約 5.7 秒でほぼ一定となり，図 16 (E 部) の車輪上昇波形では，左車輪の上昇量が約 5.25 秒から約 5.6 秒にかけて約 $30 \mathrm{~mm}$ でほぼ一定となっている. $30 \mathrm{~mm}$ は車輪フランジ高さに相当し, 左車輪は $30 \mathrm{~mm}$ 上昇後にそのまま軌条輪上にフランジ着地走行している状況であることを示す (後述の図 21(b)の左車輪の状況). したがって, 軌条輪が左端から右方向に移動する状況の中で，左側の車輪がフランジ着地走行となり，軌条輪に 対して相対的に左方向に変位しようとするため（後述の図21(a)から(b)へ移行しようとするため), 輪軸と軌条輪 との左右変位の乘離が大きくなったと考える。また，図 17 （E部）では約 5.25 秒から約 5.6 秒にかけて，フラン ジ走行中の左車輪の横圧は継続してプラス側（台車中心側）すなわち右方向に作用し，また右車輪の横圧は継続 してマイナス側（台車外側）すなわち右方向に作用している.これは，輪軸が軌条輪に対して相対的に左方向に 滑っている状況を示す。また，右車輪は 5.6 秒付近（図 17 の矢印）で再度マイナス側（台車外側）すなわち右方 向に増加する．これは，輪軸の軌条輪に対する相対変位が大きくなり脱線防止ガードが右車輪の背面に作用した ことを示す（後述の図 21(b)の右車輪の状況）。また，参考として図 19 に進行方向前軸の横圧測定結果を示す（輪 
重・横圧に関しては前軸も測定上の問題がないため)。図 19 において図 17 とほぼ同一のタイミング（E 部の 5.6 秒付近）で右車輪に生じる背面横圧がより顕著であることから，これにより脱線防止ガードが作用していること を確認できる. その結果, 図 16 の左車輪の上昇量は 5.7 秒付近で 0 となり, 図 14 の輪軸と軌条輪の左右変位は 5.75 秒付近で一致しており，脱線防止ガードが有効に作用したことが確認できる.

上記のフランジ走行以外に，加振周波数 $1.2 \mathrm{~Hz}$ といった比較的周波数が高い場合の車両挙動の特徵を以下に示 す. 図 14 の 4 秒付近を例にとると, 軌条輪が右端から折り返す時, 図 15 の車両各部のロール角はマイナス側（反 時計周り）のピーク值をとる.これは，前述の(1)加振周波数 $0.6 \mathrm{~Hz}$ の場合（図 7 と図 8 の関係）とほぼ逆の傾向 である.この理由は，加振周波数が $1.2 \mathrm{~Hz}$ の場合には，車両の上心ロール固有振動数と近いため，上心ローリン グとなるためである。この結果，車体の上部を回転中心として，軌条輪が右端に位置する時は車両の下部が右に 移動し, 軌条輪が左端に位置する時には車両の下部が左に移動するように傾く. 図 15 に示すように, 車体・台車・ 輪軸の各部ともほぼ同じタイミングでロール運動し, 図 16 のように, ロール運動がピークのときに車輪上昇がピ

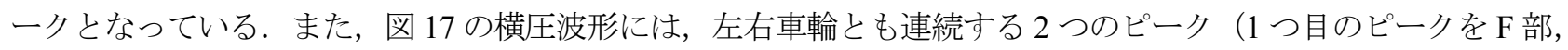
2 つ目のピークを $\mathrm{G}$ 部）が見られる.1つ目の横圧のピーク（F 部）は，図 14 で軌条輪が左右端位置から折り返 して移動を開始した直後（F 部，3.65 秒付近，4.1 秒付近）であり，且つ，図 16 （F 部）においてはちょうど車輪 が着地しようとしているタイミングであり，折り返してきた軌条輪が横から車輪に衝突するという状況である. 軌条輪の動きから見れば, 図 11 の周波数 $0.6 \mathrm{~Hz}$ の場合と同等のタイミングでピークが発生するが, 車両の動きを 関連づけると大きく異なる．また，2つ目の横圧のピーク（G 部）は，図 14 で軌条輪が中央位置を通過した直後 （G 部，3.85 秒付近，4.3 秒付近）で，その時，図 16 （G 部）において車輪は急激に上昇しようとする. ただし， これらの横圧の発生タイミングは，加振する周波数や振幅の大小に応じて異なってくると考えられ，あくまでこ の加振条件での特徴として捉えることとする．その他の特徵としては，加振振幅は小さいものの加速度が大きい ため, 図 17 , 図 18 に示すように車輪・レール間の接触力（横圧・輪重）は, 低周波で加振する場合よりも大き くなる.

以上 2 つの加振条件での時刻歴応答波形を基に，車両挙動を詳細に示した．加振条件の違いによって，車両の ロール運動や車輪・レール間で生じる力は異なるが，軌条輪の左右方向の動きによって車両に慣性力が作用し， その結果，車体が大きくローリングしながら，車両がロッキングして車輪が上昇することを示した.

また，実物の車輪がフランジ着地走行の状況で，軌条輪に設けた脱線防止ガードが車輪に作用することにより 脱線を防止することを確認し，挙動を詳細に示すことができた.

今回観測した車輪上昇挙動と脱線メカニズムは, 表 1 に示す手法で我々が過去に得た知見とも一致している.

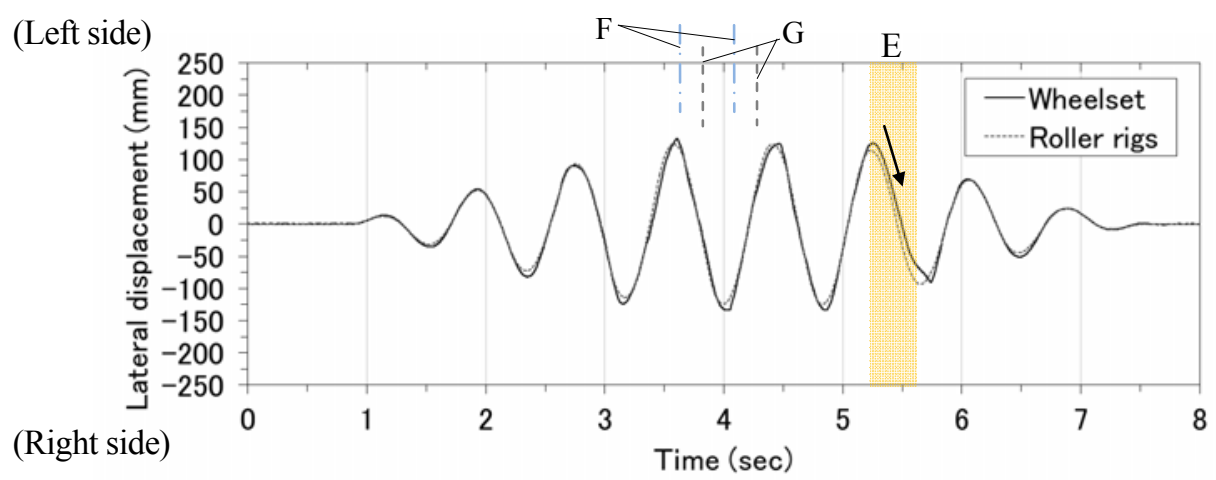

Fig.14 Lateral displacement of a wheelset and roller rigs(frequency $1.2 \mathrm{~Hz}$, maximum amplitude $124 \mathrm{~mm}$ ) 


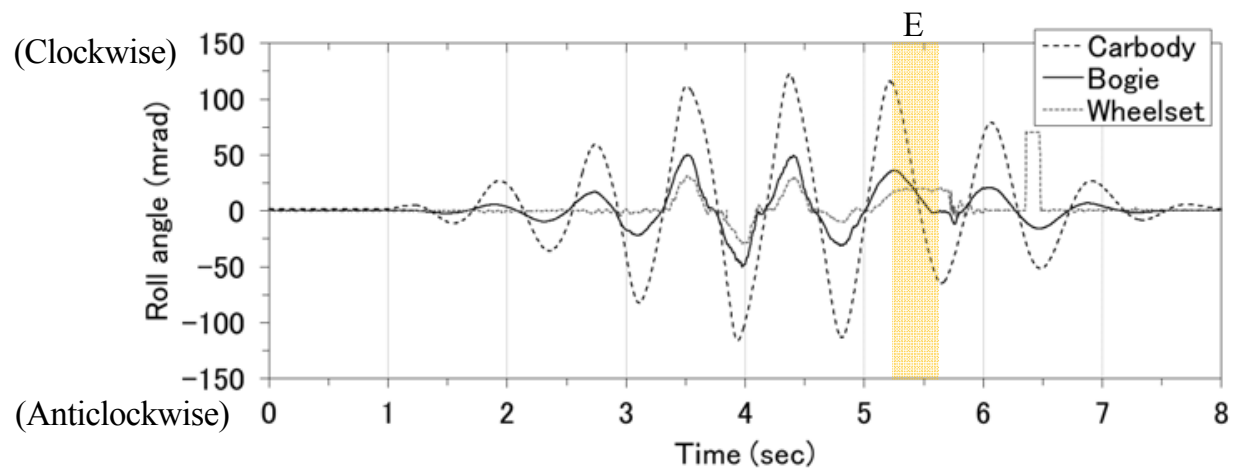

Fig.15 Roll angle of a carbody, bogie and wheelset (frequency $1.2 \mathrm{~Hz}$, maximum amplitude $124 \mathrm{~mm}$ )

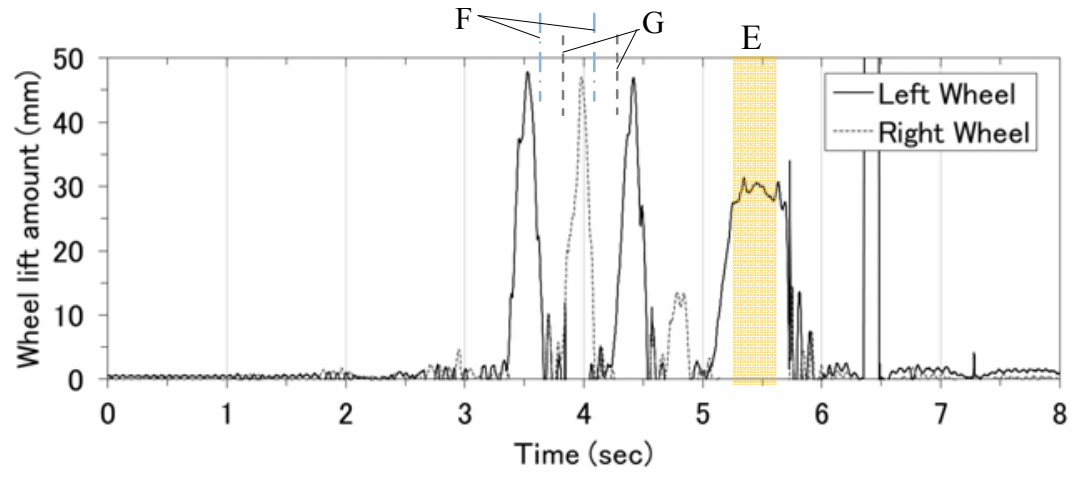

Fig.16 Lift amount of a left and a right wheel (frequency $1.2 \mathrm{~Hz}$, maximum amplitude $124 \mathrm{~mm}$ )

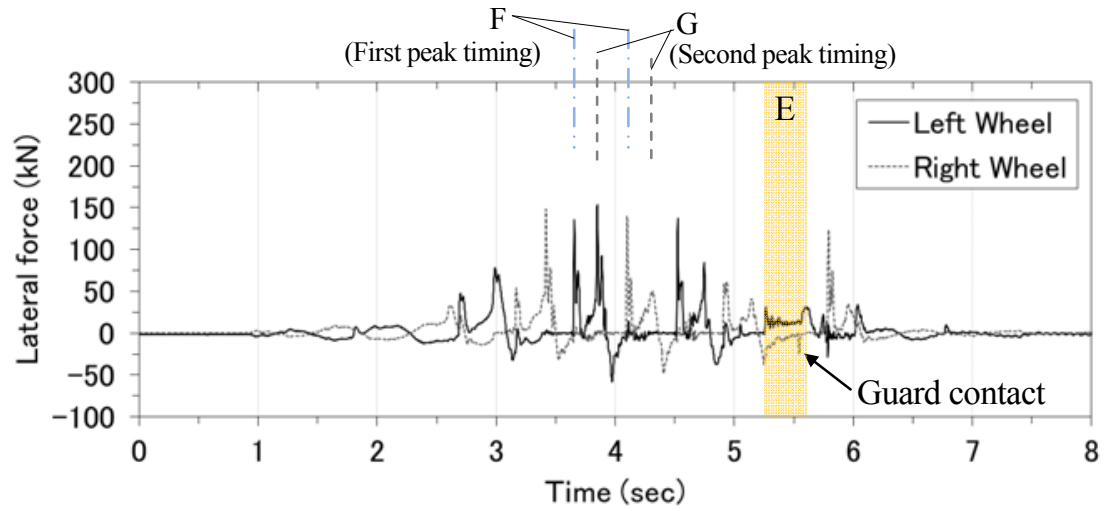

Fig.17 Lateral contact force between wheels and roller rigs (frequency $1.2 \mathrm{~Hz}$, maximum amplitude $124 \mathrm{~mm}$ )

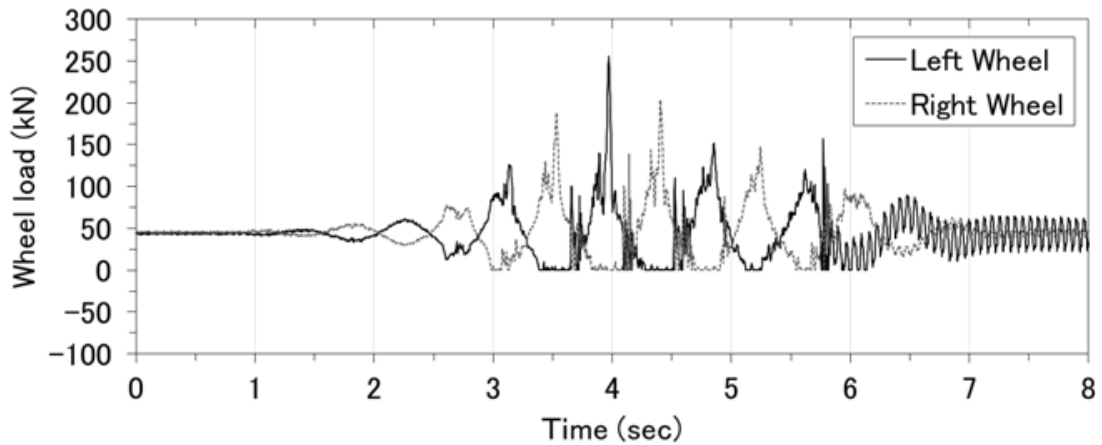

Fig.18 Vertical contact force between wheels and roller rigs (frequency $1.2 \mathrm{~Hz}$, maximum amplitude $124 \mathrm{~mm}$ ) 


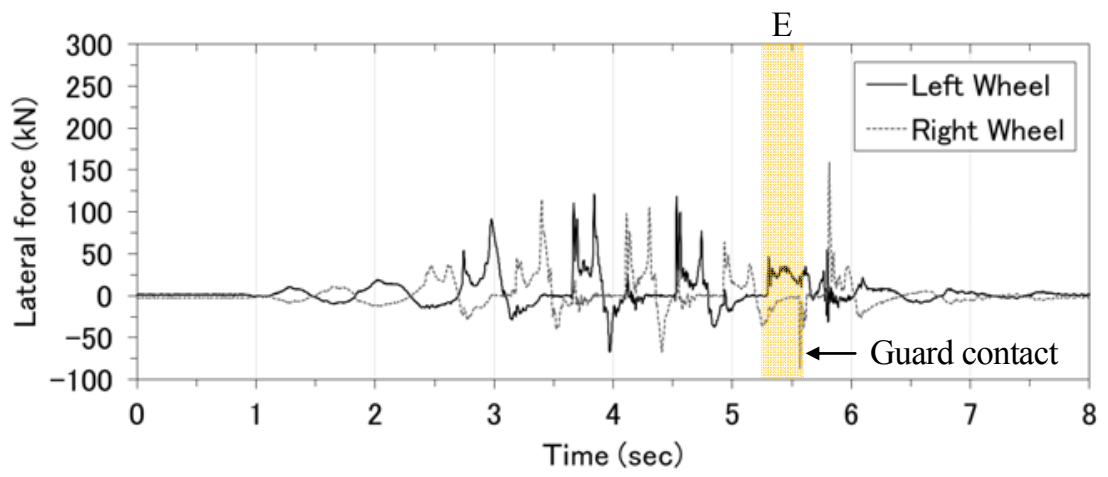

Fig.19 Lateral contact force between wheels and roller rigs (front wheels datum, Reference)

\section{$4 \cdot 2$ 実台車加振試験（車輪回転）の走行安全限界}

図 20 は, 正弦波加振試験において，1 台車内の 4 輪何れかの車輪上昇量が $30 \mathrm{~mm}$ に到達する（もしくは初め て越える）時の加振条件（周波数と振幅）を○印でプロットした結果を示す．例えば，図 20 の周波数 $0.6 \mathrm{~Hz}$ の ○印は，前節 $4 \cdot 1$ 節(1)の加振条件である. $4 \cdot 1$ 節(1)の図 10 の車輪上昇量の結果から，30mm を少し越えている ことが確認できる，車輪上昇量が $30 \mathrm{~mm}$ を越える場合，図 21(a)で車輪フランジが左右方向においてレールと接 触できない状態であり脱線挙動に至る可能性があるため，この○印を走行安全性限界のひとつの目安とみなす. ただし，周波数 $0.5 \mathrm{~Hz} ， 1.5 \mathrm{~Hz}$ では，試験装置の制約から十分な車輪上昇が生じるところまで実施できなかった ためプロットしていない.

次に，の印については，それぞれの加振周波数において実施した最大振幅条件を示す（必ずしも脱線防止ガー ドが作用した条件ではない)。○印よりも振幅を大きくして実施した理由は，実物車輪回転状態で車輪上昇量が $30 \mathrm{~mm}$ を超える時の車両の挙動や脱線防止ガードの作用時の挙動を確認することである.この結果, 周波数 $1.2 \mathrm{~Hz}$ （振幅 $124 \mathrm{~mm} ， 125 \mathrm{~mm}$ ）と $1.3 \mathrm{~Hz}$ （振幅 $120 \mathrm{~mm}$ ）においてのみ，図 $21\left(\mathrm{~b}\right.$ )および図 $22^{(13)}$ に示すような脱線挙 動および脱線防止ガードの作用を確認することができた.

その他の周波数 $0.6 \mathrm{~Hz}, 0.8 \mathrm{~Hz}, 1.0 \mathrm{~Hz}, 1.1 \mathrm{~Hz}$ では，安全上，脱線挙動および脱線防止ガードの作用を確認す るところまで振幅を上げることはできなかった．特に， $1.0 \mathrm{~Hz}$ と $1.1 \mathrm{~Hz}$ の最大振幅条件では，車輪上昇量の最大 值が $60 \mathrm{~mm}$ に達するところまで確認したが，輪軸が軌条輪に対して横移動せず，車輪は元の位置に着地したため 図21(b)のようなフランジ着地走行には至らなかった。

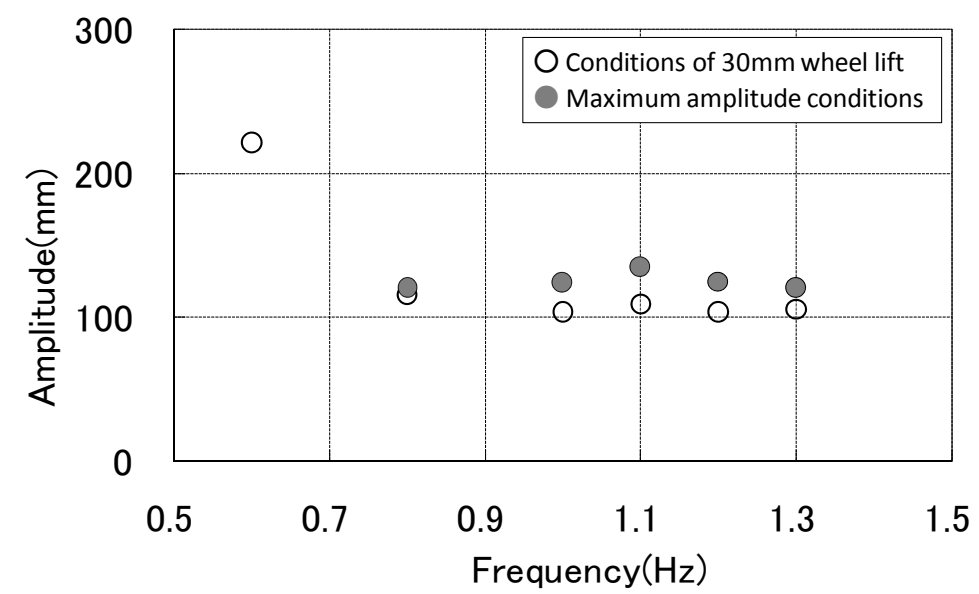

Fig.20 Excitation amplitudes for 30mm wheel lift (field test simulator at a speed of $150 \mathrm{~km} / \mathrm{h}$ ) 


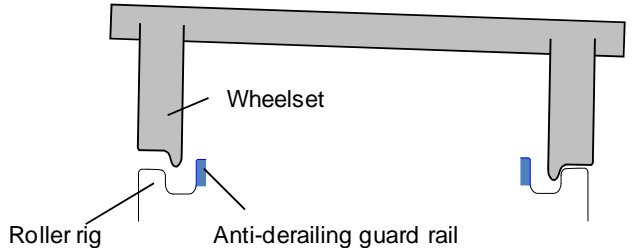

(a) Wheel lift amount $\geq 30 \mathrm{~mm}$

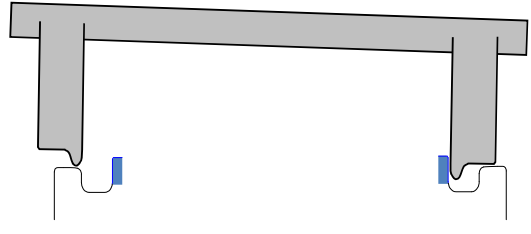

(b) Guard action

Fig.21 Relation between a wheelset and roller rigs

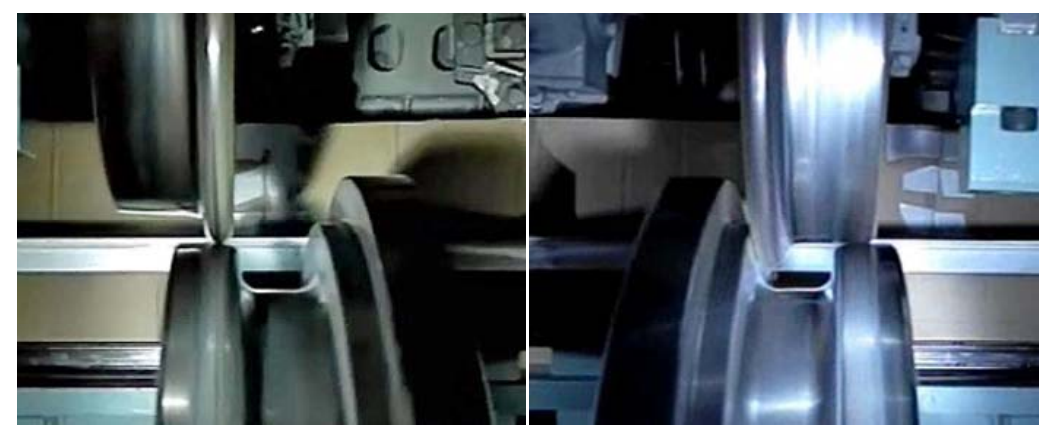

Fig.22 A left wheel flange running on roller rig and a right wheel prevented by an anti-derailing guard rail ${ }^{(13)}$

\section{4·3 実台車加振試験（車輪回転）と数值シミュレーションとの走行安全限界比較}

図 23 は, 今回の実台車加振試験と数值シミュレーションについて, 車輪回転速度 $150 \mathrm{~km} / \mathrm{h}$ 相当で車輪上昇量 が $30 \mathrm{~mm}$ を越えるときの加振条件をプロットしたものである. 数值シミュレーションについては, 既報告の文献 (10)(11)の車両モデル(半車体モデル)と軌道モデルを用い，今回の実台車加振試験と同一の加振波形（但し加振振幅 は $5 \mathrm{~mm}$ 刻みで実施）を用い，車輪回転速度 $150 \mathrm{~km} / \mathrm{h}$ で計算した結果である。

図 23 の結果から，実台車加振試験（○印）とシミュレーション（実線）は概ね一致していることがわかる. このシミュレーションは，今回の実台車加振試験をモデル同定したものではない.したがって，軌条輪と軌道モ デル (柔支持) の違い，車輪・レール間のクリープ力の違い，加振振幅の刻み幅の違い等により，両者の結果が 異なることも考えられたが，車輪上昇 $30 \mathrm{~mm}$ 時の加振振幅にそれほど大きな差は見られなかった. したがって， このような大変位加振により車輪上昇量が $30 \mathrm{~mm}$ となるような場合は，前述の影響は比較的小さく，これまで使 用しているシミュレーションモデルは大変位加振時の実物の現象を概ね予測しうるものであると判断することが できる.

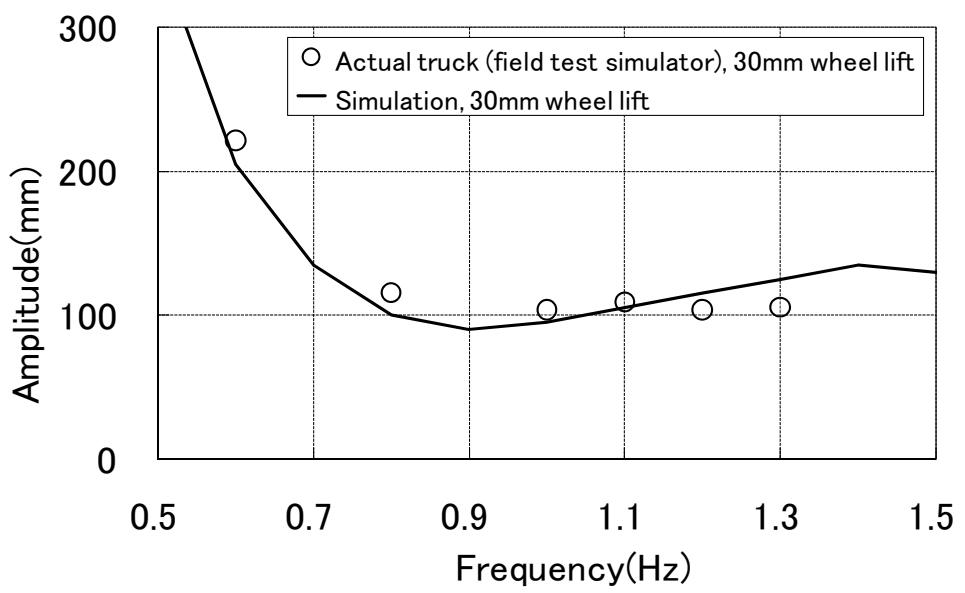

Fig.23 Comparison between an actual truck test by the field test simulator and simulation (at a speed of $150 \mathrm{~km} / \mathrm{h}$ ) 


\section{4·4 実台車加振（車輪回転）と実台車振動台試験（車輪停止）との走行安全限界比較}

図 24 に，今回の車両走行試験装置（車輪回転速度 $150 \mathrm{~km} / \mathrm{h} ）$ の実台車試験と，過去に実施した試験用バラス 卜軌道上での実台車振動台試験について, 車輪上昇 $30 \mathrm{~mm}$ が生じる振幅条件の比較結果を示す。この結果, 実台 車加振試験（O印）と実台車振動台試験（・印）はほぼ一致することがわかる．このことから，車輪上昇 $30 \mathrm{~mm}$ 時の加振振幅に関しては車輪回転速度の影響があまり大きくないということを，この実台車試験による比較によ って実証することができた。この傾向はシミュレーションの既報告文献の結果（図 $25^{(10)}$ ，停止時と $300 \mathrm{~km} / \mathrm{h}$ の 比較）と同じ傾向である. したがって, $4 \cdot 3$ 節に加え，この比較からもシミュレーションモデルは大变位加振時 の実物の現象を概ね予測しうるものと判断する.

また，今回の速度影響は車輪上昇 $30 \mathrm{~mm}$ の振幅に対する車輪回転速度の影響を示した結果であり，脱線挙動そ のものが生じる振幅（脱線防止ガードが作用する振幅）に対する影響を議論するものではない. 脱線挙動が生じ る振幅に対する車輪回転速度の影響を議論する場合は, 片側の車輪が $30 \mathrm{~mm}$ 以上に上昇した状況(図 21(a))で, もう片側の車輪がレールに対して横移動(図 21(b))しやすいかどうかを議論することとなる. 本試験結果ではその 議論は対象外であるが, 過去のシミュレーション(10)(11) と軌条輪上での $1 / 10$ 模型加振試験(9)では, 加振周波数が比 較的低い場合に，脱線挙動が生じる振幅に対し車輪回転速度の影響が生じることを把握済みである.

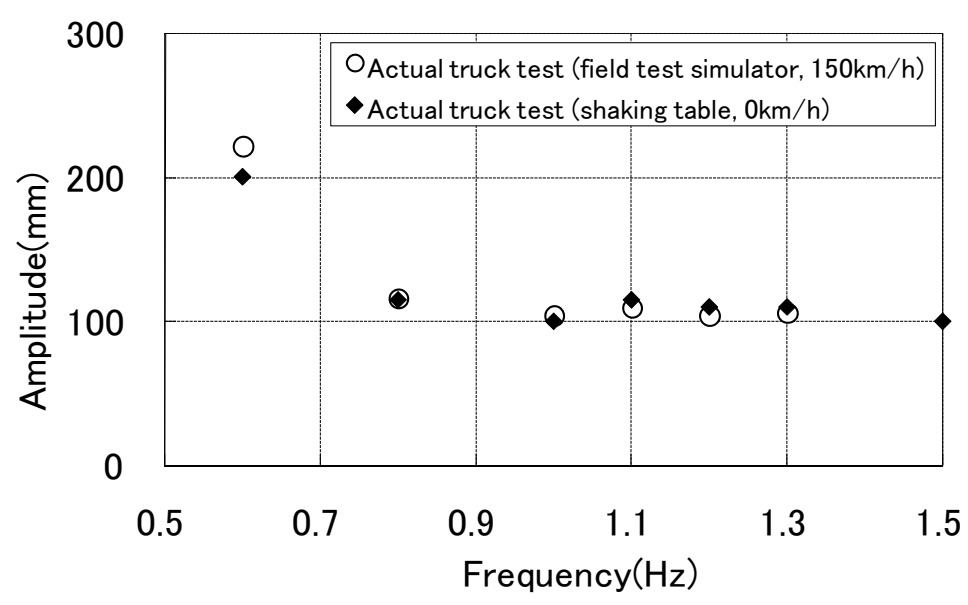

Fig.24 Comparison between the field test simulator and shaking table test concerning $30 \mathrm{~mm}$ wheel lift

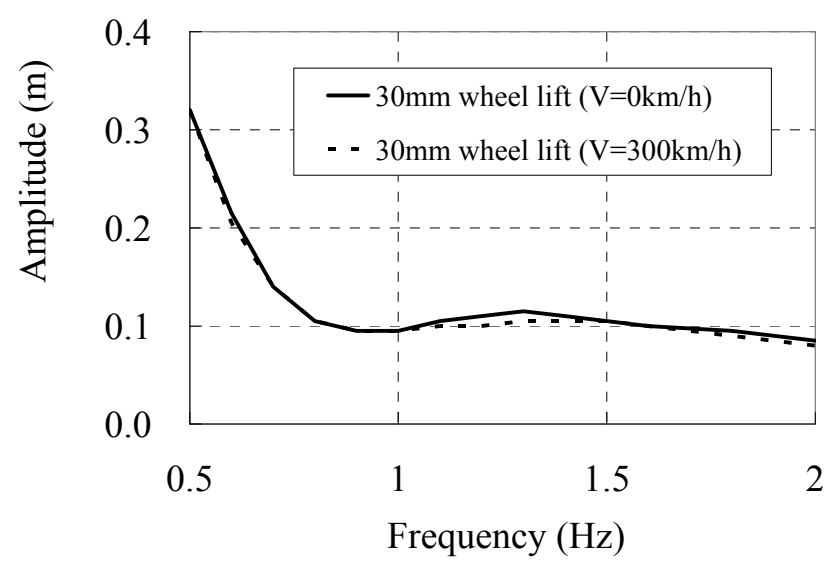

Fig.25 Excitation amplitudes for $30 \mathrm{~mm}$ wheel lift according to wheel rotation speed by simulations ${ }^{(10)}$ 


\section{5. 結}

実際の N700 系台車と車体荷重を模擬した荷重枠により, 実物大の半車体一台車モデルを軌条輪上に載せ, 車輪回転速度 $150 \mathrm{~km} / \mathrm{h}$ で, 地震を模擬した大変位加振試験を実施した，その結果，以下の結論を得た．

（1） 大変位加振時の車両挙動について，代表例として加振周波数が比較的低い場合 $(0.6 \mathrm{~Hz})$ と比較的高い場 合 $(1.2 \mathrm{~Hz}$, 東海地震で想定される高架橋応答波の最大加速度付近の周波数)について軌条輪と車両各部の変位およ び輪重・横圧の時刻歷応答波形を分析し，車輪上昇および脱線メカニズムを詳細に調べた．その結果，車輪上昇 は，軌条輪の左右方向の動きによって車両に左右方向の大きな慣性力が作用し，上心・下心のローリング特性に 応じて車体が大きくローリングし，車両全体がロッキングすることに起因することを示した．このロッキング挙 動は，過去に行った実験やシミュレーション結果と一致する. また， $1.2 \mathrm{~Hz}$ および $1.3 \mathrm{~Hz}$ の加振試験では，ロッ キング挙動により $150 \mathrm{~km} / \mathrm{h}$ でフランジ着地走行となったが，脱線防止ガードが車輪に作用し脱線を防止するこ とを実証することができた。

（2）実台車 $(150 \mathrm{~km} / \mathrm{h}$ 車輪回転）での正弦波加振試験について，加振周波数毎に車輪がフランジ高さ相当 $(30 \mathrm{~mm})$ 上昇するときの振幅条件を走行安全限界として整理した．そして，過去に実施したシミュレーションと比較し， 車輪上昇 $30 \mathrm{~mm}$ の加振振幅は概ね一致することを確認した．このことから，シミュレーションモデルは，大変位 加振時の実物の現象を概ね予測しうるものと考える.

(3) 今回の実台車加振試験 $(150 \mathrm{~km} / \mathrm{h}$ 車輪回転) と過去の実台車振動台試験 (車輪停止) について, 車輪上昇 $30 \mathrm{~mm}$ となる振幅条件の比較を行った，その結果，両者の振幅はほぼ一致することを確認した．このことは，車輪上昇 $30 \mathrm{~mm}$ となる振幅条件に関し，走行速度の影響はあまり見られないことを示寸．この傾向は，過去のシミュレー ションと同じ結果であり, このことからもシミュレーションモデルは大変位加振時の実物の現象を予測しうるも のと考える.

以上より，車輪回転状態で確認した車輪上昇挙動や脱線のメカニズムは，表 1 の方法で過去得られた知見と基 本的に一致しており，よりいっそう知見を深めることができたと考える.

\section{謝辞}

本研究にあたり，同所属の森下佳孝氏には，車両走行試験装置による実台車加振試験で取得したデータの処理 に関し, また同所属の車両走行試験装置 $\mathrm{G}$ と車両運動 $\mathrm{G}$ 諸氏には, 試験実施において多大なご助力を賜った. こ こに感謝申し上げる.

\section{文献}

（1）宮本岳史，石田弘明，松尾雅樹，“地震時の鉄道車両の挙動解析(上下,左右に振動する軌道上の車両運動シミュレ ーション)”，日本機械学会論文集 C 編，Vol. 64, No. 626 (1998), pp. 236-243.

（2）宮本岳史，曽我部正道，下村隆行，西山幸夫，松本信之，松尾雅樹，“実台車加振実験による大変位車両運動シミ ユレーションの検証”，鉄道総研報告，Vol. 17, No. 9 (2003), pp. 39-44.

（3）宮本岳史，松本信之，曾我部正道，下村隆行，西山幸夫，松尾雅樹，“大変位軌道振動による実物大鉄道車両の加 振実験”，日本機械学会論文集 C 編，Vol. 71, No. 706 (2005),pp. 59-65.

（4）宮本岳史, 野上雄太, 室野剛隆, “地震時の車両挙動の解明と地震防災一の適用（その3） 地震波から脱線可能性 を推定する方法”，第14 回鉄道技術連合シンポジウム（J-RAIL2007）講演論文集，pp. 221-224.

（5）関口勇太，宮本昌幸，“鉄道車両の地震に対する走行安全性向上策の検討”，第 16 回鉄道技術連合シンポジウム （J-RAIL2009）講演論文集，pp. 519-522.

（6）森村勉，関雅樹，石川栄，坂上啓，三輪昌弘，村松浩成，西村和彦，吉田幸司，足立昌仁，南善徳，“実物台車振 動台実験による鉄道車両の地震時脱線メカニズムの検証”, 日本機械学会論文集 C 編, Vol.76, No.764 (2010), pp. 41-50. 
(7) 森村勉, 関雅樹, 三輪昌弘, 坂上啓, 村松浩成, 西村和彦, “地震時の脱線に対する脱線防止ガード機能の実物台 車振動台実験”, 日本機械学会論文集 C, Vol.76, No.771 (2010), pp. 340-346.

(8) 森村勉, 足立昌仁, 石川栄, 深田淳司, 瞱道佳明, “地震時の脱線メカニズムと脱線防止ガード機能に関する研究 （1/5 模型加振試験）”，日本機械学会論文集 C 編，Vol.76, No. 770 (2010), pp. 102-109.

（9）西村和彦，瞱道佳明，森村勉，深田淳司，“振動軌条輪における模型鉄道車両の走行安全性に関する実験的研究”, 日本機械学会論文集 C 編, Vol.75, No. 749 (2009), pp. 58-65.

（10）西村和彦, 瞱道佳明, 森村勉, 曽我部潔, “振動軌道上における高速鉄道車両の走行安全性に関する解析的研究”, 日本機械学会論文集 C 編，Vol. 74, No. 744 (2008), pp. 93-100.

(11) 西村和彦, 曄道佳明, 森村勉, 曾我部潔, “振動軌道上における高速鉄道車両の走行安全性に関する解析的研究(輪 軸ヨーイングを考慮するモデルでの検討)”，日本機械学会論文集 C 編，Vol. 75, No. 753 (2009), pp. 90-96.

(12) 森村勉, 西村和彦, 瞱道佳明, 兽我部潔, “地震時の脱線メカニズムおよび脱線防止ガード機能に関する解析”, 日本機械学会論文集 C 編，Vol. 76, No. 770 (2010), pp. 95-101.

(13) Adachi, M., Morimura, T., Terumichi, Y., Nishimura, K. and Sunami, H., "Study of Mechanism and Countermeasures Effects on Preventing Derailment and Deviation during Earthquakes", Proceeding of Speed-up and Service Technology for Railway and Maglev System 2012 (STECH 2012).

(14) 森村勉, 関雅樹, “新潟県中越地震後の東海道新幹線の地震対策について”, 第 16 回鉄道技術連合シンポジウム （J-RAIL2009）講演論文集，pp. 545-548. 